\title{
The good water quality on Cu in Jiaozhou Bay waters
}

\author{
Dongfang Yang ${ }^{1,2,3, \text { a , Sixi Zhu }}{ }^{1,2}$, Fengyou Wang ${ }^{1,2, b}$, Ming Wang ${ }^{1,2}$ and \\ Xiuqin Yang ${ }^{1,2}$
}

${ }^{1}$ Research Center for Karst Wetland Ecology, Guizhou Minzu University, Guiyang 550025, China;

${ }^{2}$ College of Chemistry and Environmental Science, Guizhou Minzu University, Guiyang 550025, China;

${ }^{3}$ North China Sea Environmental Monitoring Center, SOA, Qingdao 266033, China.

adfyang_dfyang@126.com; ${ }^{b}$ corresponding author fywang@163.com.cn

Keywords: $\mathrm{Cu}$, Content, pollution level, Sources, Jiaozhou Bay.

\begin{abstract}
We analyzed the contents, horizontal distributions and pollution sources of $\mathrm{Cu}$ in Jiaozhou Bay, Shandong Province, China in 1984. Results showed that $\mathrm{Cu}$ contents in surface waters in July, August and October 1984 were $0.28-1.88 \mu \mathrm{g} \mathrm{L}^{-1}, 1.60-4.00 \mu \mathrm{g} \mathrm{L}^{-1}$ and $0.11-2.00 \mu \mathrm{g}$

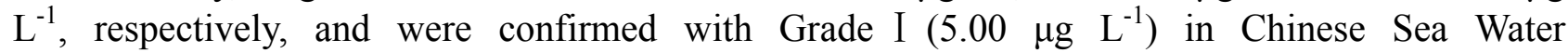
Quality Standard (GB 3097-1997). The major sources of $\mathrm{Cu}$ were river flow and ocean current, whose source strengths were $1.88-4.00 \mu \mathrm{g} \mathrm{L}^{-1}$ and $2.00 \mu \mathrm{g} \mathrm{L}^{-1}$, respectively. The source strengths and pollution levels of $\mathrm{Cu}$ in Jiaozhou Bay were very weak and low in 1984. These founding were helpful to understanding the background level of $\mathrm{Cu}$ in the early stage of reform and opening up, as well as the research on the existence of $\mathrm{Cu}$.
\end{abstract}

\section{Introduction}

$\mathrm{Cu}$ is one of the most wide distribution heavy metal elements whose major forms are copper sulfide and copper oxide, and has been widely used in metallurgical, machine manufacturing, chemical plating etc. A large amount of $\mathrm{Cu}$-containing waste water was generated along with the rapid increasing of industry and discharged to the rivers and then transported to the ocean [1-2]. However, the excessive of $\mathrm{Cu}$ in the marine environment is harmful to eco-environment, as well as human being. Hence, the research on the pollution levels and sources of $\mathrm{Cu}$ in the marine bay is helpful to marine environmental protection. This paper analyzed the pollution levels and sources of $\mathrm{Cu}$ in waters in Jiaozhou Bay, a semi-closed bay located in Shandong Province, China, and provided background information of $\mathrm{Cu}$ contents and sources strengths for further study, as well as practices on environmental remediation.

\section{Materials and method}

Jiaozhou Bay $\left(35^{\circ} 55^{\prime}-36^{\circ} 18^{\prime} \mathrm{N}, 120^{\circ} 04^{\prime}-120^{\circ} 23^{\prime} \mathrm{E}\right)$ is located in Shandong Province, eastern China (Fig. 1). The total area of the bay is $446 \mathrm{~km}^{2}$, while the width of the bay mouth is only about $2.5 \mathrm{~km}$. In the east, north and west of the bay are cities of Qingdao, Jiaozhou and Jiaonan, while the bay mouth is located in the south of the bay, and is connected with the Yellow Sea. This bay has more than ten inflow rivers, such as Dagu River, Loushan River, Licun River and Haibo River, all of which are strongly determined by rainfall-runoff, and are showing significant seasonal features [3-4].

The data was provided by North China Sea Environmental Monitoring Center, State Ocean Administration. The investigation on $\mathrm{Cu}$ in surface waters at six sampling sites $(2031,2032,2033$, 2034, 2035 and 2047) in was carried on in July, August and October 1984. The sampling and measurement of $\mathrm{Cu}$ was following by Chinese Specification for Marine Monitoring [5]. 


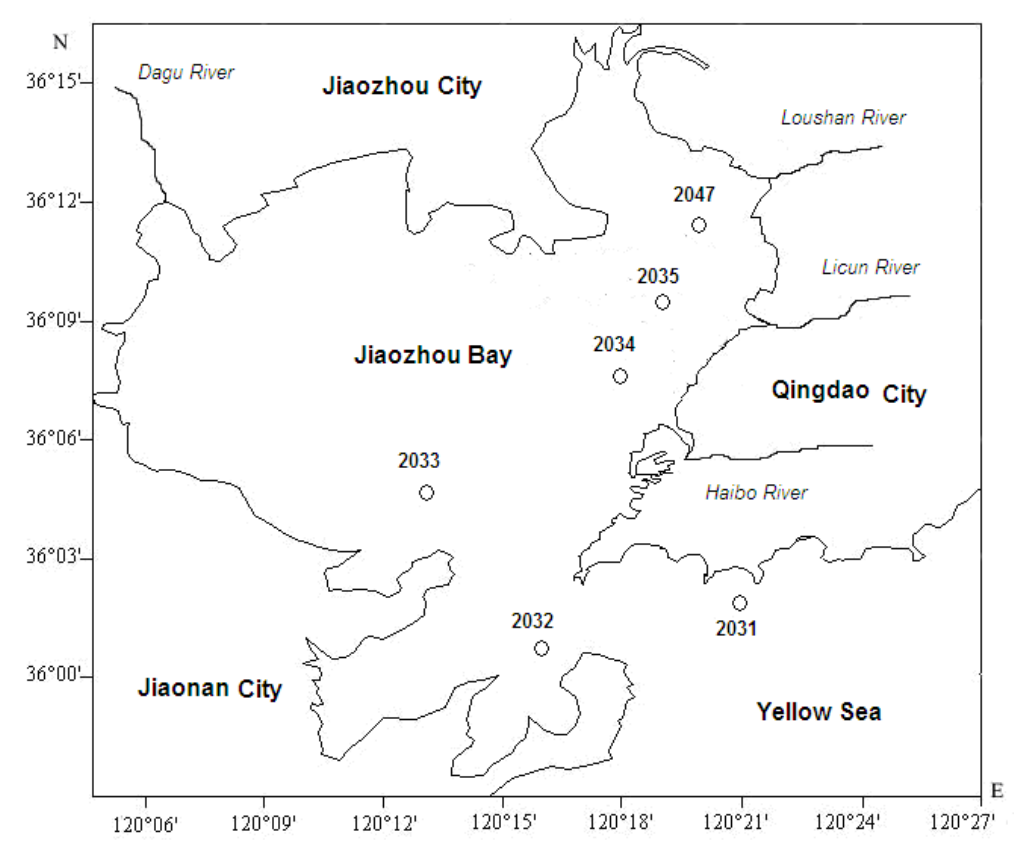

Fig. 1 Geographic location and sampling sites in Jiaozhou Bay

\section{Contents and pollution levels of $\mathrm{Cu}$}

$\mathrm{Cu}$ contents in surface waters in July, August and October 1984 were $0.28-1.88 \mu \mathrm{g} \mathrm{L} \mathrm{L}^{-1}$, 1.60-4.00 $\mathrm{g} \mathrm{L}^{-1}$ and $0.11-2.00 \mu \mathrm{g} \mathrm{L}^{-1}$, respectively (Table 1), and were confirmed with Grade I in according to Chinese Sea Water Quality Standard (GB 3097-1997). For detail, Cu contents in waters in the bay in July were $1.83-1.88 \mu \mathrm{g} \mathrm{L}^{-1}$, wile in the open waters were $0.28-0.40 \mu \mathrm{g} \mathrm{L}^{-1}$. Cu contents in the bay were higher than in the open waters. In August, $\mathrm{Cu}$ contents in the bay and the open waters were closed. In October, $\mathrm{Cu}$ contents in waters in the bay were $0.00-0.90 \mu \mathrm{g} \mathrm{L}^{-1}$; while in the open waters were $2.00 \mu \mathrm{g} \mathrm{L}^{-1}$. In generally, $\mathrm{Cu}$ contents in July in the bay were higher than in the open waters, yet in October were reverse. However, the pollution level of $\mathrm{Cu}$ in different seasons in 1984 was very low.

Table $1 \mathrm{Cu}$ content in surface water in Jiaozhou Bay in July, August and October 1984

\begin{tabular}{|c|c|c|c|}
\hline Time & July & August & October \\
\hline Content $/ \mu \mathrm{g} \mathrm{L}^{-1}$ & $0.28-1.88$ & $1.60-4.00$ & $0.11-2.00$ \\
\hline Grade & $\mathrm{I}$ & $\mathrm{I}$ & $\mathrm{I}$ \\
\hline
\end{tabular}

\section{Horizontal distributions of $\mathrm{Cu}$}

In July, there was a high value zone in Site $2034\left(1.88 \mu \mathrm{g} \mathrm{L}^{-1}\right)$ in the estuary of Haibo River in the northeast of the bay, and the contour lines were forming a series of parallel lines, which were decreasing from the high value center to in the northeast to bay mouth $\left(0.28 \mu \mathrm{g} \mathrm{L}^{-1}\right)$ (Fig. 2). In August, there was a high value zone in Site $2035\left(4.00 \mu \mathrm{g} \mathrm{L}^{-1}\right)$ in the estuary of Licun River in the northeast of the bay, and the contour lines were forming a series of semi-concentric circles, which were decreasing from the high value center to in the northeast to bay mouth $\left(1.60 \mu \mathrm{g} \mathrm{L}^{-1}\right)$. In October, there was a high value zone in Site $2031\left(2.00 \mu \mathrm{g} \mathrm{L}^{-1}\right)$ in the open waters, and the contour lines were forming a series of parallel lines, which were decreasing from the high value center to in the northeast to bay mouth $\left(0.90 \mu \mathrm{g} \mathrm{L}^{-1}\right)$, and to the northeast of the bay $\left(0.11 \mu \mathrm{g} \mathrm{L}^{-1}\right)$ (Fig. 3). 


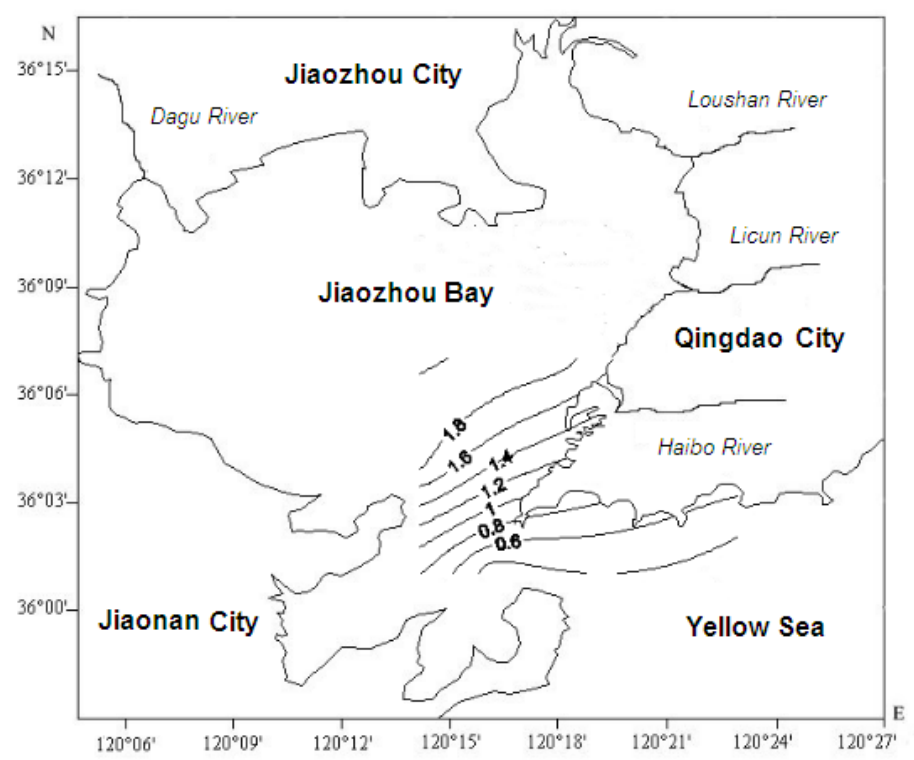

Fig. 2 Horizontal distributions of $\mathrm{Cu}$ in surface waters in Jiaozhou Bay in July 1984

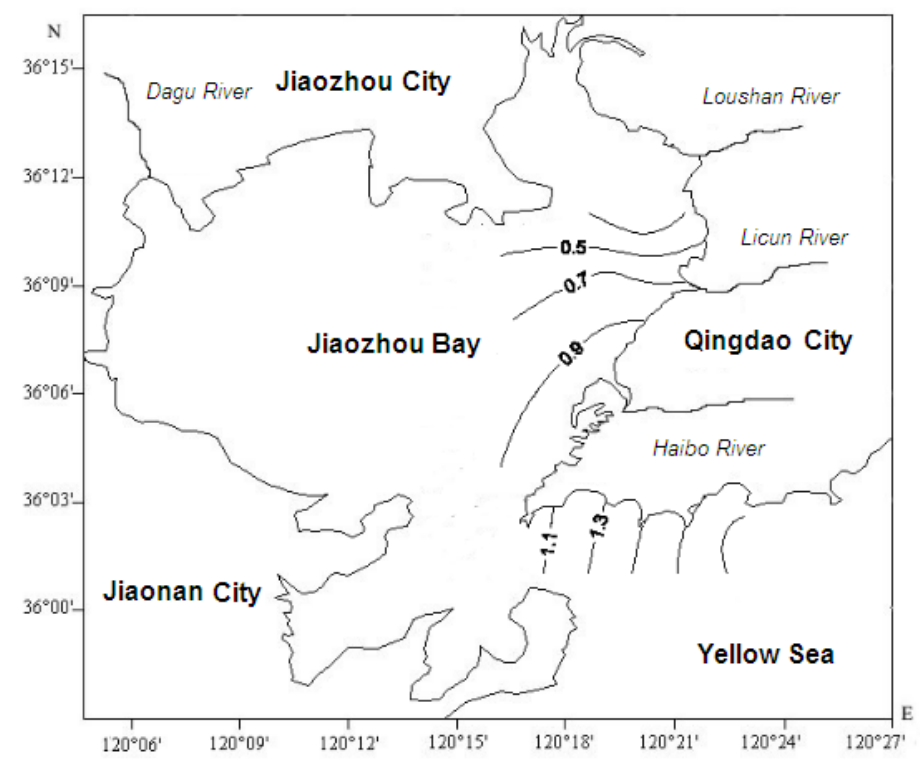

Fig. 3 Horizontal distributions of $\mathrm{Cu}$ in surface waters in Jiaozhou Bay in October 1984

\section{Sources and source strengths of $\mathrm{Cu}$}

High value region of $\mathrm{Cu}$ contents were occurring in the estuary of Haibo River in July, yet $\mathrm{Cu}$ contents in the bay mouth were very low, indicated stream flow was the major source of Cu in July. There were also high value region $\mathrm{Cu}$ contents in estuaries of Licun River, indicated stream flow was also the major source of $\mathrm{Cu}$ in August. However, high value region of $\mathrm{Cu}$ contents were in the open waters in October, and $\mathrm{Cu}$ contents were decreasing from the open waters to the bay mouth, indicated marine current was the major source of $\mathrm{Cu}$ in October. In according to the highest value, it could be defined that the source strengths of stream flow and marine current were $1.88-4.00 \mu \mathrm{g} \mathrm{L}^{-1}$ and $2.00 \mu \mathrm{g} \mathrm{L}^{-1}$, respectively (Table 2). However, the source strengths were still very low, so as the $\mathrm{Cu}$ contents in the bay.

Table 2 Sources and source strengths of Cu in Jiaozhou Bay 1984

\begin{tabular}{|c|c|c|}
\hline Source & Stream flow & Marine current \\
\hline Source strength $/ \mu \mathrm{g} \mathrm{L}^{-1}$ & $1.88-4.00$ & 2.00 \\
\hline
\end{tabular}




\section{Conclusions}

$\mathrm{Cu}$ contents in surface waters in July, August and October 1984 were $0.28-1.88 \mu \mathrm{g} \mathrm{L} \mathrm{L}^{-1}$, 1.60-4.00 $\mu \mathrm{g} \mathrm{L}^{-1}$ and 0.11-2.00 $\mu \mathrm{g} \mathrm{L}^{-1}$, respectively, and were confirmed with Grade I . The major sources of $\mathrm{Cu}$ were stream flow and marine current, whose source strengths were 1.88-4.00 $\mu \mathrm{g} \mathrm{L}^{-1}$ and $2.00 \mu \mathrm{g} \mathrm{L}^{-1}$, respectively. The source strengths and pollution levels of $\mathrm{Cu}$ in Jiaozhou Bay were very weak and low in 1984. These founding were helpful to understanding the background level of $\mathrm{Cu}$, and the research on the existence of $\mathrm{Cu}$ in the bay.

\section{Acknowledgement}

This research was sponsored by Doctoral Degree Construction Library of Guizhou Nationalities University, Education Ministry's New Century Excellent Talents Supporting Plan (NCET-12-0659), the China National Natural Science Foundation (31560107) and Research Projects of Guizhou Nationalities University ([2014]02), Research Projects of Guizhou Province Ministry of Education (KY [2014] 266), Research Projects of Guizhou Province Ministry of Science and Technology (LH [2014] 7376).

\section{References}

[1] Yang DF, Miao ZQ, Song WP, et al.: Advanced Materials Research, Vols.1092-1093 (2015), p. 1013-1016.

[2] Yang DF, Miao ZQ, Cui WL, et al.:Advances in intelligent systems research, Vol. (2015), p.17-20.

[3] Yang DF, Chen Y, Gao ZH, Zhang J, et al.:Chinese Journal of Oceanology Limnology, Vol. 23(2005): 72-90.

[4] Yang DF, Wang F, Gao ZH, et al.: Marine Science, Vol. 28 (2004:71-74).

[5] State Ocean Administration. The specification for marine monitoring: Beijing, Ocean Precess, (1991). 